REPORTS OF MORPHOLOGY
Official Journal of the Scientific Society of Anatomists,
Histologists, Embryologists and Topographic Anatomists
of Ukraine
journal homepage: https://morphology-journal.com

\title{
Galectin-3 as the marker of hypertrophy and myocardial dysfunction in males with essential hypertension, carriers of polymorphic genes of angiotensin II type 1 receptor
}

\section{Ruzhanskaya V.O., Sivak V.G., Sakovych O.O., Zhebel V.M.}

National Pirogov Memorial Medical University, Vinnytsya, Ukraine

\section{ARTICLE INFO}

Received: 14 March, 2018

Accepted: 3 April, 2018

UDC: [(616.12-008.331.1) $055.1+(616.127: 616-007.61)-$ $055.1+575.113](477)$

\section{CORRESPONDING AUTHOR}

e-mail: ruganskaya@gmail.com Ruzhanskaya V.O.

\begin{abstract}
One of the main etiological causes of development of heart failure is essential hypertension. The diagnosis of heart failure is usually made on the basis of comprehensive analysis of medical history, sonographic and biochemical examination. Normal ejection fraction does not exclude dyspnea of cardiac origin. Objective: to determine the role of galectin-3 as a marker of structural and functional changes of the myocardium in males with essential hypertension and CHF, carriers of polymorphic AT1R genes, residents of Podillya region of Ukraine. In this contingent, the surveyed were studied concentrations of galectin-3 and brain natriuretic peptide (BNP), parameters of central and systemic hemodynamics in carriers of polymorphic variants of angiotensin II type 1 receptor gene (AT1R) - individuals with no cardiovascular pathology ( $n=79)$, male patients with II-III degree essential hypertension (EH) and hypertrophy of the myocardium $(n=62)$, and essential hypertension $(n=50)$ complicated by chronic heart failure (CHF), residents of Podillya region of Ukraine, were studied. Genotyping of AT1R gene was performed using polymerase chain reaction. Galectin-3 and brain natriuretic peptide levels were determined by enzyme immunoassay. Structural and functional parameters of myocardium were assessed by ultrasound using the apparatus "RADMIR ULTIMARA". Statistical analysis of the results obtained was done on personal computer using standard statistical package Statistica 10.0. The data are represented as mean values $(M)$ and standard deviations $( \pm \sigma)$. Carriers of $C$ allele of angiotensin II type 1 receptor gene were found to be dominating among the males with essential hypertension and resultant myocardial hypertrophy. Concentrations of galectin-3 and brain natriuretic peptide were significantly higher in men with essential hypertension and essential hypertension associated with chronic heart failure, as compared to those with no cardiovascular diseases, as well as the carriers of $C$ allele of angiotensin II type 1 receptor gene. It was found that concentrations of study biomarkers were higher in individuals with severe and eccentric left ventricular hypertrophy, as well as in those with decreased ejection fraction of the left ventricle. Therefore, those biomarkers can be used in complex diagnosis of left ventricular hypertrophy in essential hypertension and the development of chronic heart failure in such patients.

Keywords: polymorphism of angiotensin II type 1 receptor gene (AT1R), galectin-3, brain natriuretic peptide, structural and functional changes in the myocardium, essential hypertension, chronic heart failure.
\end{abstract}

\section{Introduction}

Over the last decades, heart failure (HF) has become not only the most significant and rapidly progressive medical, but also an important social problem in many economically developed countries, as it leads to early disability of patients, reduced quality of life and its duration [29]. According to the European Society of Cardiology (ESC) [22], essential hypertension is a major cause of CHF. Traditionally, CHF and its severity are associated with decreased systolic function of the left ventricle (LV), which is usually evaluated by its ejection fraction (EF). However, in some patients, the signs of inadequate blood supply are observed even in slightly modified or normal LV systolic function. The 
percentage of this group of patients is quite high - 35\%-50\% [15]. Asymptomatic diastolic dysfunction (DD) occurs in $28 \%$ of American population (age 67 years), and in $27 \%$ of European population (age 58 years). $17-25 \%$ of patients diagnosed with CHF die within 12 months after hospitalization [13]. Because of that, success in timely diagnosis, prevention and treatment of $\mathrm{EH}$ and $\mathrm{CHF}$ on its background, are closely related to study of mechanisms of their development and progression [2, 22].

During the last 20 years the role of AT1R polymorphism in the development of $\mathrm{EH}$ and $\mathrm{CHF}$ is emphasized. A number of such studies were carried out among the residents of Podillya region. In studies conducted by Sakovich O.O. [24], the inheritance of genotypes of AT1R gene with the presence of allele C-AC and CC - by female patients with EH was proved to be associated with primary identification of severe and eccentric left ventricular hypertrophy (LVH), DD by pseudonormal and restrictive types, systolic dysfunction of the LV myocardium. Inheritance of CC genotype by EH female patients with the signs of heart failure stage IIA was associated with higher levels of blood pressure (BP): systolic BP (SBP) - irrespective of the state of LV systolic function, and diastolic blood pressure (DBP) - in those with left ventricular systolic dysfunction. In the study of Starzhynska O.L., the carriage of C allele of AT1R gene was found to be associated with significantly high risk of developing hypertensive disease in males, residents of Podillya region, and the presence of $\mathrm{C}$ allele significantly correlated with pronounced pathological changes in the state of the heart and vascular endothelium [25].

In the study by Chandra S. et al. (2014), carriership of allele $C$ of AT1R gene was found to be associated with high levels of blood pressure and development of essential hypertension, as well as high cardiovascular risk [10].

Two phenotypic responses in the form of $\mathrm{CHF}$ with different values of LV EF may be associated with the same initial reasons. Several studies have demonstrated that formation of any CHF phenotype can be associated with certain genetic factors, such as polymorphism of cytokine axis genes, NO-synthetase, angiotensin converting enzyme and AT1 receptors, fibroblast growth factor superfamilies, tumor necrosis factor-alpha, receptors to endogenous catecholamines [8, 9, 20].

Taking into consideration the fact that intensity of heart and vessels remodeling is associated with antiinflammatory reaction of low intensity, being realized by involvement of promitotic, prooxidant, fibroplastic and neurohumoral factors, one of the methods to assess the contribution of these factors in evolution of HF is the use of molecular biological indicators [5]. To improve the prognosis and to determine the risk of cardiovascular mortality in patients with $\mathrm{HF}$, the search is made for biomarkers that would increase the probability of accurate diagnosis in the presence of a small number of clinical symptoms.

The reference marker for the diagnosis of acute $\mathrm{CHF}$ and its exacerbation is brain natriuretic peptide (BNP) [1].
One of the main advantages of BNP use is the possibility to distinguish dyspnea of cardiac origin from dyspnea caused by respiratory system pathology [22]. One of relatively new biomarkers is galectin-3. Its expression is minimal or practically absent in healthy individuals, as well as in patients with cardiovascular diseases in remission or compensatory stage [16]. At the same time, it is maximal at the peak of development of cardiac muscle fibrosis. Galectin-3 practically is not found in cardiomyocytes, whereas its high levels are found in myocardial fibroblasts [21]. In the myocardium galectin-3 stimulates rapid increase of myofibroblast number and release of procollagen 1 in extracellular matrix through paracrine effect, leading to cardiac fibrosis [26]. When there are no clinical manifestations of $\mathrm{HF}$ but the ejection fraction (EF) is reduced, galectin-3 level can increase [11]. The probability of 1.5 times increase in galectin-3 level in Ukrainian patients with CHF and EH were noted in the study conducted by Tseluyko V.I. et al. [27]. However, no additional factors were considered, namely the etiology of $\mathrm{EH}$, presence of left ventricular hypertrophy (LVH) and its variants, the carriership of polymorphic variants of AT1R gene, etc. The question arises of whether it is possible to consider galectin-3 a marker not only of the fibrosis processes in the myocardium, which clearly can be marked in overt CHF, but also of their beginning in the development of either type of hypertrophy. On the other hand, to what extent are those processes influenced by the carriership of AT1R gene, which can be a factor causing the development of $E H$ and CHF? Understanding these processes can contribute to more effective primary and secondary prevention of chronic heart failure.

It is galectin-3 that is the marker of the same fibrotic processes underlying CHF. So another question arises of whether it is possible to use galectin-3 levels for screening of candidates for the development of $\mathrm{CHF}$ in $\mathrm{EH}$.

Objective: to determine the role of galectin-3 as a marker of structural and functional changes of the myocardium in males with essential hypertension and $\mathrm{CHF}$, carriers of polymorphic AT1R genes, residents of Podillya region of Ukraine.

\section{Materials and methods}

The study was performed according to the standards of proper clinical practice and the principles of Helsinki Declaration. A written informed consent was received before enrollment of participants in the study.

The following males - residents of Podillya region were studied: 79 men aged $40-60$, average age $57.06 \pm 0.50$ years, with no signs of cardiovascular disease, 62 men, average age $49.19 \pm 0.66$ years, with stage II hypertensive disease and 50 men, average age $50.14 \pm 0.99$ years, with $\mathrm{EH}$ complicated by CHF. During enrollment of males in the groups of patients with stage II EH and $\mathrm{EH}$ complicated by $\mathrm{CHF}$, the following factors were considered: verified diagnosis of $\mathrm{EH}$ (with obligatory exclusion of symptomatic hypertension), the presence of LVH, confirmed by clinical 
and instrumental examinations. Exclusion criteria were symptomatic arterial hypertension, impaired renal function and liver, coronary heart disease developed prior to $\mathrm{EH}$, endocrine, hematological, neoplastic and autoimmune disorders, complications of $\mathrm{EH}$ - myocardial infarction, acute cerebrovascular accident. In study patients with $\mathrm{EH}$, the diagnosis of concomitant coronary artery disease was excluded after assessment of pre-test probability of the disease on the basis of simple clinical indicators complaints, anamnesis of the disease, detailed data analysis of outpatient cards of patients, results of ECG at rest and ultrasound examination of the heart at rest.

All the males were inpatients at Vinnytsia Regional Specialized Clinical Hospital of Radiation Protection of Ministry of Health of Ukraine and Military Medical Clinical Center of Central Region of Air Forces of Ukraine, and were also observed on outpatient basis from December 2013 to July 2014.

To determine alleles of polymorphic site (A1166C) of angiotensin II type 1 receptor (AT1R) gene, genomic DNA was isolated from venous blood leukocytes using "Set for separation of DNA/RNA from blood serum or blood plasma" (Private enterprise "Scientific Production Company "LitTech", Russia).

Blood sampling was done in fasting state from cubital vein in the amount of $4 \mathrm{ml}$ whole blood into cooled polypropylene tubes, containing EDTA $(1 \mathrm{mg} / 1 \mathrm{ml}$ of blood). The collected material was stored at $-20^{\circ} \mathrm{C}$ for no more than 6 months before the analysis initiation. Polymerase chain reaction technique was used. Genotyping of AT1R gene was carried out in cooperation with Scientific and Research Institute of Genetic and Immunological Foundations of Pathology and Pharmacogenetics at Higher State Educational Institution "Ukrainian Medical Academy of Dentistry" (Poltava, chief - prof. Kaidashev I.P). To determine alleles of polymorphic site (A1166C) of AT1R gene, genomic DNA was isolated from venous blood leukocytes.

To determine plasma concentration of BNP in study patients, strip immunoassay analyzer "HumaReader single" (Germany) at wavelength of $450 \mathrm{~nm}$ and differential filter $620 \mathrm{~nm}$ was used, supplied with standard set of Peninsula laboratories Inc. (USA). Blood sampling for analysis was done in fasting state at 8 a.m. from cubital vein in the amount of $3 \mathrm{ml}$ whole blood by cooled syringe into cooled polypropylene tubes, containing EDTA ( $1 \mathrm{mg} / 1 \mathrm{ml}$ of blood) and aprotinin (500U per $1 \mathrm{ml}$ of blood). Immediately after sampling, the whole blood was centrifuged for 15 minutes at $0^{\circ} \mathrm{C}(1600 \mathrm{rpm})$. The resulting plasma was transferred to Ependori type polypropylene tube. Maximum period of sampling material preservation at $-32^{\circ} \mathrm{C}$ before initiation of enzyme immunoassay did not exceed 6 months.

Plasma galectin- 3 concentration of study patients was determined by enzyme-linked immunoassay using standard set of reagents produced by Bender MedSystems $\mathrm{GmbH}$ (Austria), and "Stat Fact 330" apparatus.

The analysis was carried out in clinical diagnostic laboratory of private laboratory center "Center B" (date of laboratory certification - March 5, 2014). Laboratory director S.O. Stepanets was executive in charge. Detection of galectin-3 level is indicated in attestation certificate of the laboratory. Reference value of plasma galectin-3 concentration - 0.0-2.28 ng/ml, average level - $0.54 \mathrm{ng} / \mathrm{ml}$.

Blood sampling was done in fasting state from cubital vein in the amount of $2 \mathrm{ml}$ whole blood at 8 a.m. Then $0.5 \mathrm{ml}$ of plasma was separated, time between sampling of whole blood and plasma separation was less than $30 \mathrm{~min}$. The separated plasma was frozen at $-25^{\circ} \mathrm{C}$.

Frequency distribution of polymorphic genes in the population was tested according to Hardy-Weinberg equilibrium law using GeneXpert calculator for calculation of a number of statistical parameters in case-control studies which use SNP (gen-exp.ru). ECG registration was done according to conventional method using 12 standard leads. Blood pressure was measured according to recommendations of WHO experts. Evaluation of parameters of systemic and intracardiac hemodynamics was performed using echocardiography on echogram RADMIR ULTIMARA (Kharkiv, Ukraine). Left ventricular muscle mass index (LVMMI) was calculated using Penn Convention formula: $L V M M I=1.04\left[(E D S+P W T+I V S T)^{3}-E^{-} S^{3}\right]-13.6$, where EDS end diastolic size, PWT - posterior wall thickness, IVST intraventricular septum thickness. LVMMI $\geq 115 \mathrm{r} / \mathrm{M}^{2}$ was considered the criterion of LVH for males according to clinical recommendations of the European Society of Hypertension (ESH) and the European Society of Cardiology (ESC) to treatment of arterial hypertension (2016) [2].

LVMMI below $170 \mathrm{~g} / \mathrm{m}^{2}$ denoted moderate LVH, while that over $170 \mathrm{~g} / \mathrm{m}^{2}$ was indicative of severe LVH. Calculation of relative wall thickness (RWT) of the left ventricle by the formula $(2 \times P W d) / E D S$, where PWd - posterior wall thickness in diastole, EDS - end diastolic size) allows to distinguish increased mass of the LV to concentric (LV RWT $\geq 0.42$ ) and eccentric (LV RWT $\leq 0.42$ ) hypertrophy and allows to distinguish concentric left ventricular remodeling (normal LVMM with increasing LV RWT $\geq 0.42$ ). The following transmitral flow parameters were studied in pulsed wave Doppler regime: maximum velocity of rapid early diastolic filling $(E)$ and maximum speed $(A)$ of left ventricular filling during systole of the left atrium $(\mathrm{cm} / \mathrm{c})$, their ratio (VE/VA). Diastolic LV function was assessed according to current recommendations [22]. Systolic function of the LV myocardium was evaluated by ejection fraction (EF). EF $>40 \%$ was indicative of preserved systolic function.

Mathematical processing was performed on a personal computer using standard statistical package "Statistica 10.0".

For initial preparation of tables and intermediate calculations Microsoft Excel package was used.

Calculated the primary statistical indicators, identified the differences between the groups by statistical characteristics. All data is presented in the form of average $(\mathrm{M})$ and standard deviation $( \pm \sigma)$. Differences between the 
samples distributed according to the law of normal distribution, were evaluated for Student's t-criterion ( $t$ ) for unbound measurements.

\section{Results}

Considering vital importance of $\mathrm{C}$ allele carriership as one of the prognostic signs of $\mathrm{EH}$, as has been emphasized earlier, we conducted frequency distribution of gene variants and alleles of AT1R gene among males, residents of Podillya region of Ukraine, ill with $\mathrm{EH}$ and resultant CHF. According to the data obtained, the distribution was found to correspond to Hardy-Weinberg equilibrium. Predominance of genotype frequency which include $C$ allele of AT1R gene was found in males with $\mathrm{EH}$ and $\mathrm{CHF}$, included in study population, (Fig. 1 ), this being consistent with other authors.

To make further analysis easier both in patients with $\mathrm{EH}$, and $\mathrm{EH}$ and $\mathrm{CHF}$, as well as in the group of individuals with no cardiovascular disease, - those with genotypes which include $C$ allele (A1166C and C1166C), it was decided to combine them in one group - the carriers of AT1R gene $C$ allele.

According to results obtained in the study of biomarkers concentrations, plasma level of galectin- 3 and BNP in patients with $\mathrm{EH}$ of various stages, men of 40-60 years, residents of Podillya region of Ukraine, are different depending on the constitutional characteristics, severity of the disease and inheritance of different genotypes of AT1R gene. It is noteworthy, that among the patients with $\mathrm{EH}$, regardless of the stage of disease, higher plasma concentrations of galectin-3 and brain peptide were identified in the carriers of $C$ allele than in homozygotes A1166A of AT1R gene. Galectin-3 level was found to be was significantly higher in male patients with $\mathrm{EH}$ and $\mathrm{CHF}$ as compared to those with stage II EH $(p<0.05)$ (Table 1).

Pathophysiology of $\mathrm{CHF}$ is directly related to remodeling of the LV, fibrosis of the myocardium being one of its characteristic features [17]. Galectin-3 induces the

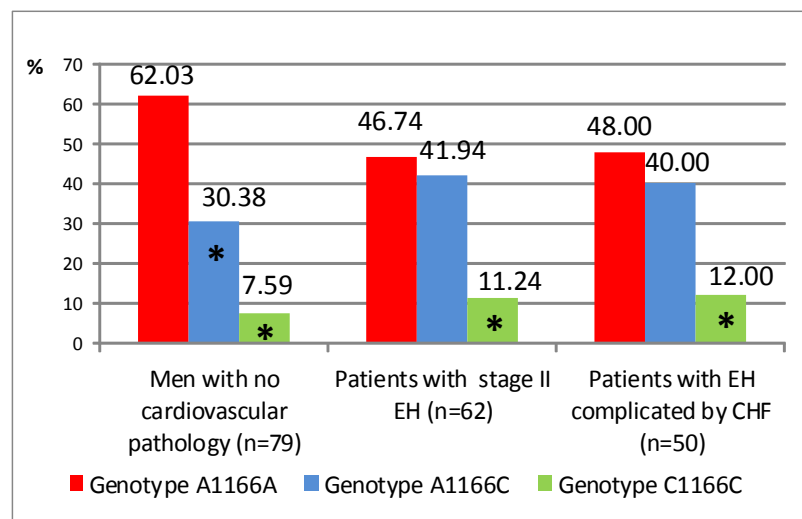

Fig. 1. Frequency distribution of genotypes of AT1R gene among males, residents of Podillya region of Ukraine, with stage II EH and $\mathrm{EH}$ complicated by $\mathrm{CHF},(\%)$. ${ }^{*}$ - difference between the indices is significant $(p \leq 0.05)$ when compared with A1166A genotype within the group.

processes of proliferation of fibroblasts, collagen synthesis and expression of cycline D1. Table 2 presents the levels galectin-3 and BNP in male patients with $\mathrm{EH}$ at different stages of LV hypertrophy.

According to our data, galectin-3 and BNP levels were significantly higher in the carriers of AT1R gene $C$ allele and in the patients with severe and eccentric LV hypertrophy.

The next step was to determine the changes of biomarkers in the development of different variants of myocardial dysfunction.

Among male patients with stage II EH, diastolic dysfunction was registered in 8 patients $(40.00 \%)$ homozygotes of $A 1166 \mathrm{~A}$ genotype, and 12 patients $(60.00 \%)$ - carriers of AT1R gene C allele ( $p>0.05)$. It should be noted that no systolic dysfunction was registered in patients with stage II EH.

Normal transmitral flow (TMF) and preserved diastolic function was observed in 21 individuals $(72.41 \%)$ homozygotes of A1166A genotype, and 22 patients (66.67\%)

Table 1. Blood plasma galectin-3 and BNP levels in males with no cardiovascular pathology, patients with EH and EH complicated by CHF, carriers of different variants of AT1R gene $(\mathrm{ng} / \mathrm{ml}, \mathrm{pcg} / \mathrm{ml})$.

\begin{tabular}{|c|c|c|}
\hline Groups & Blood plasma galectin-3 level & Blood plasma BNP level \\
\hline Males with no cardiovascular pathology $(n=79)$ & $7.031 \pm 0.127(n=79)(1)$ & $21.74 \pm 0.5(n=79)(1)$ \\
\hline Homozygotes of A1166A genotype & $6.824 \pm 0.251(n=49)(2)$ & $20.05 \pm 2.02(n=49)(2)$ \\
\hline C allele carriers & $7.363 \pm 0.405(n=30)(3)$ & $21.88 \pm 0.62(n=30)(3)$ \\
\hline Patients with stage II EH $(n=62)$ & $21.31 \pm 0.22(n=62)(4)$ & $77.40 \pm 2.85(n=62)(4)$ \\
\hline Homozygotes of A1166A genotype & $20.82 \pm 0.51(n=29)(5)$ & $56.56 \pm 0.90(n=29)(5)$ \\
\hline C allele carriers & $22.87 \pm 0.56(n=33)(6)$ & $88.79 \pm 2.97(n=33)(6)$ \\
\hline Patients with $\mathrm{EH}$ and $\mathrm{CHF}(n=50)$ & $46.65 \pm 2.18(n=50)(7)$ & $185.9 \pm 5.7(n=50)(7)$ \\
\hline Homozygotes of A1166A genotype & $44.27 \pm 2.77(n=24)(8)$ & $163.5 \pm 6.8(n=24)(8)$ \\
\hline C allele carriers & $59.23 \pm 3.39(n=26)(9)$ & $216.2 \pm 5.3(n=26)(9)$ \\
\hline $\mathbf{P}$ & $\begin{array}{c}\mathbf{p}_{3-2}>0.05 ; p_{4-1}<0.0001 ; p_{5-2}<0.0001 ; \\
p_{6-3}<0.0001 ; p_{6-5}<0.05 ; p_{7-1}<0.0001 ; \\
p_{7-4}<0.0001 ; p_{8-2}<0.0001 ; p_{8-5}<0.0001 ; \\
p_{9-3}<0.0001 ; p_{9-6}<0.0001 ; p_{9-8}<0.05\end{array}$ & $\begin{array}{c}\mathbf{p}_{3-2}>0.05 ; \mathbf{p}_{4-1}<0.0001 ; \mathbf{p}_{5-2}<0.0001 ; \\
\mathbf{p}_{-6-3}<0.0001 ; \mathbf{p}_{6-5}<0.05 ; \mathbf{p}_{7-2}<0.0001 ; \\
\mathbf{p}_{7-4}<0.0001 ; \mathbf{p}_{8-2}<0.0001 ; \mathbf{p}_{8-5}<0.0001 ; \\
\mathbf{p}_{9-3}<0.0001 ; \mathbf{p}_{9-6}<0.0001 ; \mathbf{p}_{9-8}<0.05\end{array}$ \\
\hline
\end{tabular}


Table 2. Blood plasma galectin-3 and BNP levels in male patients with stage II EH and various types of LV hypertrophy, carriers of polymorphic variants of AT1R gene $(\mathrm{ng} / \mathrm{ml}, \mathrm{pcg} / \mathrm{ml})$.

\begin{tabular}{|c|c|c|c|c|c|}
\hline Patient group & $\begin{array}{c}1 . \text { Galectin-3 level in AA } \\
\text { homozygotes }\end{array}$ & $\begin{array}{c}2 . \text { Galectin-3 level in } \\
\text { carriers of C alleles }\end{array}$ & $\begin{array}{c}3 \text {. BNP level in AA } \\
\text { homozygotes }\end{array}$ & $\begin{array}{c}4 . \text { BNP level in } \\
\text { cariers of C alleles }\end{array}$ & $p<0.05$ \\
\hline $\begin{array}{c}\text { 1. Patients with stage II } \\
\text { EH, CLVH (n=44) }\end{array}$ & $20.77 \pm 0.56(n=18)$ & $25.82 \pm 0.67(n=26)$ & $49.21 \pm 1.39(n=18)$ & $82.31 \pm 1.17(n=26)$ & $p_{2-1}, p_{3-4}$ \\
\hline $\begin{array}{c}\text { 2. Patients with stage II } \\
\text { EH, ELVH (n=18) }\end{array}$ & $21.99 \pm 1.34(n=7)$ & $29.15 \pm 1,00(n=11)$ & $53.59 \pm 1.01(n=7)$ & $97.73 \pm 1.20(n=11)$ & $p_{2-1}, p_{3-4}$ \\
\hline $\begin{array}{c}\text { 3. Patients with stage II } \\
\text { EH, MLVH (n=53) }\end{array}$ & $25.33 \pm 1.75(n=25)$ & $31.29 \pm 0.57(n=28)$ & $50.78 \pm 1.23(n=25)$ & $93.03 \pm 1.48(n=28)$ & $p_{2-1}, p_{3-4}$ \\
\hline $\begin{array}{c}\text { 4. Patients with stage II } \\
\text { EH, SLVH (n=9) }\end{array}$ & $32.91 \pm 0.54(n=4)$ & $38.50 \pm 0.38(n=5)$ & $49.14 \pm 1.86(n=4)$ & $93.44 \pm 1.87(n=5)$ & $p_{2-1}, p_{3-4}$ \\
\hline p<0.05 & $p_{2-1}>0.05 ; p_{3-4}>0.05$ & $p_{2-1}>0.05 ; p_{3-4}>0.05$ & $p_{2-1}>0.05 ; p_{3-4}>0.05$ & $p_{2-1}>0.05 ; p_{3-4}>0.05$ & \\
\hline
\end{tabular}

Note: CLVH - concentric left ventricular hypertrophy; ELVH - eccentric left ventricular hypertrophy; MLVH - moderate left ventricular hypertrophy; SLVH - severe left ventricular hypertrophy.

- carriers of $C$ allele $(p>0.05)$. Impaired TMF, its hypertrophic type, was registered in 7 individuals $(24.14 \%)$ - homozygotes of A1166A genotype, and 10 patients (30.30\%) - carriers of AT1R gene $C$ allele ( $p>0.05$ ) (Fig. 2).

Plasma levels of galectin-3 and BNP in patients with stage II EH and $\mathrm{EH}$ and $\mathrm{CHF}$, at different TMF types, were found to be significantly higher in carriers of AT1R gene $C$ allele than in A1166A homozygotes $(p<0.05)$. In addition, concentrations of galectin-3 and BNP in patients with $\mathrm{EH}$ and $\mathrm{CHF}$ with hypertrophic type of TMF, were higher than in those with stage II EH, both in carriers of A1166A genotype and in carriers of AT1R gene $C$ allele at the appropriate TMF type $(p<0.05)$.

Thus, males with stage II EH - A1166A homozygotes, and carriers of AT1R gene $\mathrm{C}$ allele, regardless the state of diastolic function, had higher plasma levels of galectin-3 and BNP than those with no cardiovascular pathology $(p<0.05)$, but significantly lower ones than patients with $\mathrm{EH}$ and CHF - carriers of corresponding genotypes $(p<0.05)$. The highest concentrations of galectin-3 and BNP were observed in patients with $\mathrm{EH}$ and $\mathrm{CHF}$ with diastolic dysfunction of LV and FV $<40 \%$ - carriers of AT1R gene C allele.

Analysis of frequency distribution of AT1R gene genotypes in males with $\mathrm{EH}$ and $\mathrm{CHF}$ at $\mathrm{EF}>40 \%$ and $\mathrm{EF}<40 \%$ demonstrated that the first group included 36 patients homozygotes of A1166A genotype, and the second one - 14 men - carriers of $\mathrm{C}$ allele - patients with $\mathrm{EH}$ and CHF. Carriers of AT1R gene $C$ allele significantly dominated in the group of patients with $E F<40 \%-85.71 \%(n=12)(p \leq 0.05)$ (Fig. 3$)$.

Galectin-3 and BNP levels in patients with $\mathrm{EH}$ and CHF with different ejection fraction were calculated (Fig. 4). The higher values of these biomarkers were found in patients with decreased ejection fraction. However, the degree of increase of biomarkers was different in carriers of polymorphic AT1R genes.

Significantly higher values of galectin-3, BNP, LVMMI, LP were detected in patients with $\mathrm{EH}$ and $\mathrm{CHF}$ with $\mathrm{EF}>40 \%$, carriers of AT1R gene $C$ allele, than in A1166A homozygotes.

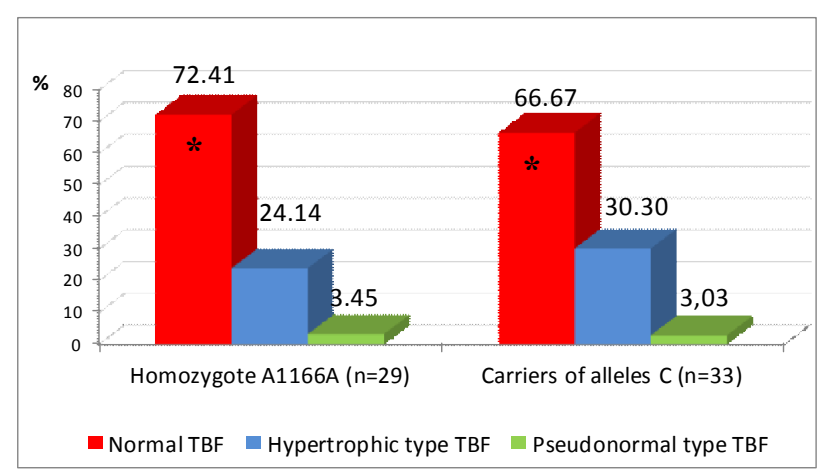

Fig. 2. Types of transmitral blood flow in male patients with stage II EH, carriers of different variants of AT1R gene, (\%). * - difference of indicators is significant at $(p<0.05)$ as compared to pseudonormal type of TMF within each group.

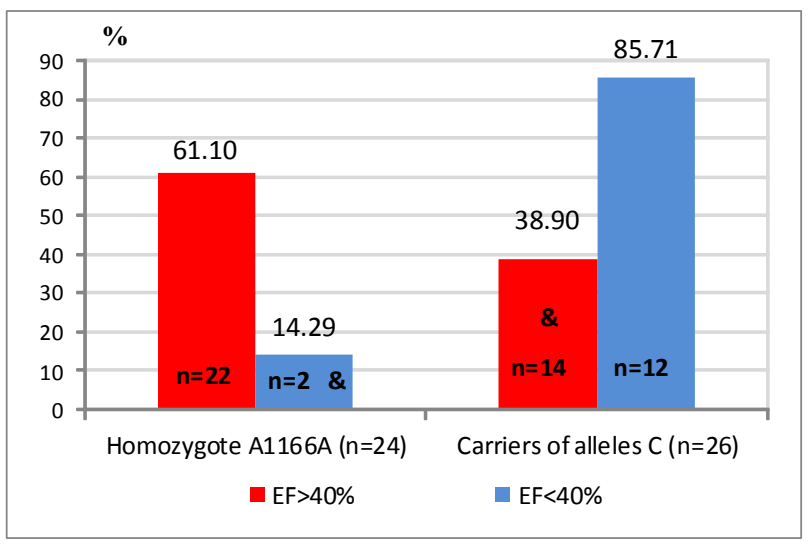

Fig. 3. Frequency distribution of AT1R gene genotypes in male patients, with $\mathrm{EH}$ and $\mathrm{CHF}$ at $\mathrm{EF}>40 \%$ and $\mathrm{EF}<40 \%$, residents of Podillya region of Ukraine, $(\%)$. \& - the difference of indicators is statistically significant $(p<0.05)$ when compared between genotypes of AT1R gene.

Hemodynamic parameters (SAP and DAP) proved to be higher in carriers of allele $\mathrm{C}$, corresponding to $\mathrm{EH}$ of II degree, and A1166A homozygotes of AT1R gene, corresponding to $\mathrm{EH}$ of I degree $(p<0.05)$.

Among patients with $\mathrm{CHF}$ and $\mathrm{EF}<40 \%$, carriers of AT1R 


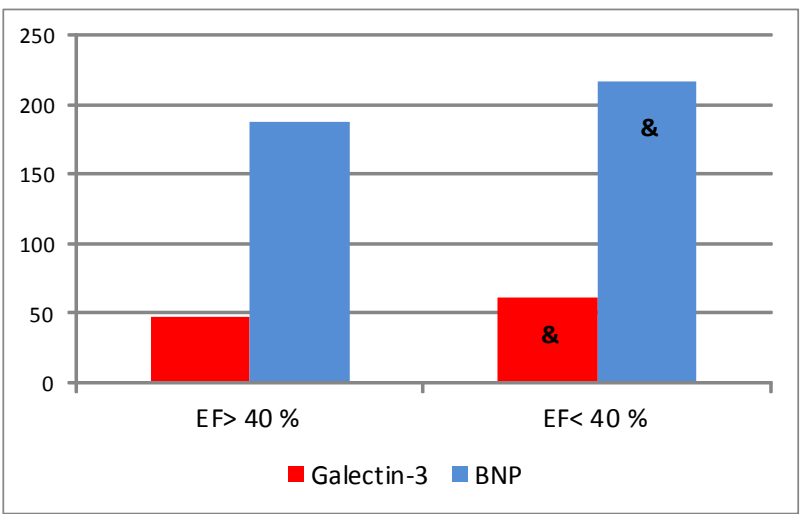

Fig. 4. Frequency distribution of $A T 1 R$ gene genotypes in male patients with $\mathrm{EH}$ and $\mathrm{CHF}$ at $\mathrm{EF}>40 \%$ and $\mathrm{EF}<40 \%$, residents of Podillya region of Ukraine, $(\mathrm{ng} / \mathrm{ml} ; \mathrm{pg} / \mathrm{ml})$. \& - difference of indicators is statistically significant $(p<0.05)$ when compared between the groups of patients with different EF.

gene $C$ allele, the highest indices of galectin-3, BNP, LVMMI, LP were registered. BP was also higher in carriers of allele $\mathrm{C}$, corresponding to III degree of $\mathrm{EH}$, and in A1166 homozygotes of AT1R gene, corresponding to II degree of $\mathrm{EH}$.

The question rose, to what extent the levels of biomarkers reflect total changes in the myocardium, leading to the development of $\mathrm{CHF}$, and whether their concentrations are influenced by myocardial hypertrophy type.

To answer those questions, first the levels of galectin-3 and BNP in eccentric left ventricular hypertrophy (ELVH) and concentric left ventricular hypertrophy $(\mathrm{CLVH})$ were analyzed. Patients with EH and CHF, with ELVH, carriers of AT1R gene $C$ allele, had higher levels of plasma concentrations of galectin-3 $(29.15 \mathrm{ng} / \mathrm{ml}$ in $\mathrm{EH}$ versus $55.16 \mathrm{ng} / \mathrm{ml}$ in $\mathrm{EH}$ and $\mathrm{CHF})$ and peptide $(97.73 \mathrm{pg} / \mathrm{ml}$ in $\mathrm{EH}$ versus $208.9 \mathrm{pg} / \mathrm{ml}$ in $\mathrm{EH}$ and $\mathrm{CHF}$ ) as compared to those with CLVH. Galectin-3 level was $25.82 \mathrm{ng} / \mathrm{ml}$ in patients with $\mathrm{EH}$ and $61.6 \mathrm{ng} / \mathrm{ml}$ in EH complicated by CHF, respectively, and peptide level was $82.31 \mathrm{pg} / \mathrm{ml}$ in uncomplicated $\mathrm{EH}$ and $198.08 \mathrm{pg} / \mathrm{ml}$ in $\mathrm{EH}$ and $\mathrm{CHF}$

The next step was the analysis of galectin-3 and BNP concentrations at EF $40 \%>$ and $<40 \%$. According to the data obtained, levels of galectin-3 (83.89 pg/ml) and BNP (229.2 $\mathrm{pg} / \mathrm{ml}$ ) were significantly higher in individuals with $\mathrm{EH}$ and $\mathrm{CHF}, \mathrm{CLVH}$ and ELVH and FV $<40 \%$, carriers of allele C.

\section{Discussion}

AT1R gene is mapped in the 3rd chromosome (3q21$3 q 25)$, it contains 5 exons, and today 16 structural polymorphisms of this gene have been described. However, it is polymorphism-change of adenine $(A)$ to cytosine $(C)$ [23] at position 1166, that is associated with essential hypertension [14, 19, 23], coronary artery disease [12] and myocardial infarction [14]. According to our data, the carriers of AT1R gene $C$ allele dominated in study population of 40 60 year old males with $\mathrm{EH}$ and $\mathrm{EH}$ complicated by $\mathrm{CHF}$, residents of Podillya region. They had higher BP levels, and there is relationship between ELVH and impaired diastolic function of the left ventricle by pseudonormal and restrictive types. These data are similar to those received by Sakovich O.O. (2011): carriership of genotypes of AT1R gene with C allele is associated not only with higher degrees of hypertension, but also with the presence of eccentric LVH and dysfunction of the left ventricle in the form of pseudonormal and restrictive types of transmitral flow, LV systolic dysfunction. Those disturbances were especially evident in patients with $\mathrm{EH}$ complicated by $\mathrm{CHF}$ [24]. In the study of Blanar O.L. and Zhebel V.M. [7] the carriership of AC genotype in male patients with $\mathrm{EH}$ was found to determine $77 \%$ probability for the development of HF with decreased systolic left ventricular function $\left(\chi^{2}=8.86, p<0.05\right)$. There is significant correlation between genotype $\mathrm{AC}$ and burdened inheritance of $\mathrm{EH}$ and early CHF signs. According to A.M. Bilovol et al. (2015), significantly higher levels of arterial pressure, more evident disturbances in structural and functional parameters of the heart and blood vessels are more typical of genotypes $A C$ and $C C$ of AT1R gene than AA genotype [6].

According to our data, levels of plasma concentrations of galectin-3 and peptide were significantly higher in patients with ELVH than those with CLVH. In the study of Beltrami M. (2016) positive correlation between increased galectin-3 level and increased LVMMI, LA sizes and severity of diastolic dysfunction were found [4]. According to Qiu-Sheng Yin et al. (2014), concentrations of galectin-3 and BNP were significantly higher in the patients with $\mathrm{EH}$ as compared to individuals with no cardiovascular diseases. Those indices were also significantly higher in patients with $\mathrm{CHF}$, developed as a complication of $\mathrm{EH}$ with reduced EF than in those with preserved ejection fraction [28].

In the works of Nikonova E.S. et al. (2013), positive correlation between the level of BNP and end systolic volume (ESV) was found only in patients with decreased EF, as well as a marked increase in the level of BNP with the progression of diastolic and systolic dysfunction [18]. Positive correlation relationship between BNP level and systolic arterial pressure, stroke volume (SV), end systolic volume (ESV) and end diastolic volume (EDV) was found by D.A. Andreev et al. (2007), that can be explained by increased intraventricular pressure and distention of the left ventricle [3].

All patients with $\mathrm{EH}$ and $\mathrm{EH}$ complicated by $\mathrm{CHF}$ had significantly higher level of galectin-3 and BNP than individuals with no cardiovascular disease, and it was significantly higher in those with $\mathrm{EH}$ and $\mathrm{CHF}$ in $\mathrm{FV}<40 \%$, thus, those biomarkers can be used for screening of individuals with hypertrophy and myocardial dysfunction to direct them for follow-up examination (Echocardiography).

The results of the study allow further study of galectin-3 as a biomarker of the structural and functional state of the myocardium in essential hypertension and chronic heart failure in the presence of various comorbid conditions (diseases). 


\section{Conclusions}

1. Blood concentration of galectin-3 and BNP in male patients with stage II EH and $\mathrm{EH}$ and $\mathrm{CHF}$, regardless of the level of LV EF, was significantly higher in C allele carriers than in carriers of A1166A genotype of AT1R gene $(p<0.05)$.

2. Carriership of $C$ allele in the structure of AT1R gene in patients with $\mathrm{EH}$ and CHF was associated with ELVH and impaired diastolic function by pseudonormal and restrictive types, which can be indicative of more severe disturbances

\section{References}

[1] Abuzaanona, A., \& Lanfear, D. (2017). Pharmacogenomics of the Natriuretic Peptide System in Heart Failure. Curr. Heart Fail. Rep., 14, 536-542. doi.org/10.1007/s11897-017-0365-5.

[2] Amosova, E. M. (2001). The effect of early remodeling of the left ventricle on the state of its systolic and diastolic function in patients with acute myocardial infarction in the dynamics of the hospital period. Ukrainian Cardiology Magazine, 1, 17-20.

[3] Andreev, D. A., Mazarkina, I. A., Gitel, E. N., Dobrovolsky, A. V., Kukes, V. G., Sychev, D. A., \& Khoreva, V. A. (2007). Changes in the brain natriuretic peptide in the treatment of decompensation of chronic heart failure. Creative cardiology, 1-2, 136-142.

[4] Beltrami, M., Ruocco, G., Dastidar, A. G., Franci, B., Lucani, B., Aloia, E. ... Palazzuoli, A. (2016). Additional value of galectin3 to BNP in acute heart failure patients with preserved ejection fraction. Clinica Chimica Acta., 457, 99-105. doi: 10.1016/ j.cca.2016.04.007.

[5] Berezin, A. E. (2013). Galectin-3 as a phenotypic indicator of cardiovascular risk in patients with heart failure. Zaporozhye Medical Journal, 6, 58-62.

[6] Bilovol, O. M., Shalimova, A. S., \& Kochueva, M. M. (2014). Comorbidity of hypertonic disease and type 2 diabetes is an urgent problem of modern medicine. Ukrainian Therapeutic Journal, 1, 11-17.

[7] Blanar, O. L., \& Zhebel, V. M. (2009). Polymorphism of theAT1R gene and vascular function of the endothelium in patients with chronic heart failure, which complicated the course of hypertension. Scientific herald of Uzhgorod University, 35, 39-43.

[8] Burkly, L. C., Michaelson, J. S., \& Zheng, T. S. (2011). TWEAK/ Fn14 pathway: an immunological switch for shaping tissue responses. Immunol. Rev., 244, 99-114. doi: 10.1111/j.1600065X.2011.01054.X

[9] Chacon, M. R., Richart, C., Gomez, J. M., Lucani, B., Aloia, E., Nuti, R., \& Palazzuoli, A. (2006). Expression of TWEAK and its receptor Fn14 in human subcutaneous adipose tissue. Relationship with other inflammatory cytokines in obesity. Cytokine., 33, 129-137. doi: 10.1016/j.cyto.2005.12.005.

[10] Chandra, S., Narang, R., Sreenivas, V., Bhatia, J., Saluja, D., \& Srivastava, K. (2014). Association of angiotensin II type 1 receptor (A1166C) gene polymorphism and its increased expression in essential hypertension: a case-control study. PLoS One., 9(7):e101502. doi: 10.1371/journal. pone.0101502.

[11] de Boer, R. A., Voors, A. A., Muntendam, P., van Gilst, W. H., \& van Veldhuisen, D. J. (2009). Galectin-3: a novel mediator of heart failure development and progression. Eur. J. Heart Fail., 11:811-817. doi: 10.1093/eurjhf/hfp097.

[12] Devi, N., Lakshmi, V., Padhy, K., Veerraju, P., \& Mahapatra, S. (2012). Association of ACE, AGT and AT1R gene polymorphisms with severity of Coronary Artery Disease. IOSR Journal of dental and medical scients., 2, 11-18. doi: 10.9790/0853-0241118. of the processes of relaxation and LV filling because of increased stiffness and decreased compliance of LV myocardium.

3. Determination of galectin-3 level in the study of morphological changes of the myocardium in patients with $\mathrm{EH}$ and $\mathrm{CHF}$ was as informative as the study of concentration of "reference" biomarker BNP, thus providing the use of this biological factor for bio-labeling of myocardial hypertrophy and associated functional disorders.

[13] Edelmann, F., Holzendorf, V., Wachter, R., Nolte, K., Schmidt, A. G., Kraigher-Krainer, E. ... Pieske, B. M. (2015). Galectin-3 in patients with heart failure with preserved ejection fraction: results from the Aldo-DHF trial. European Journal of Heart Failure, 17, 214-223. doi: 10.1002/ejhf.203.

[14] Kikuya, M., Sugimoto, K., Katsuya, T., Suzuki, M., Sato, T., Funahashi, J. ... Matsubara, M. (2003). A/C1166 gene polymorphism of the angiotensin II type 1 receptor (AT1) and ambulatory blood pressure: the Ohasama Study. Hypertens Res., 26:141-145.

[15] Kinoshenko, K. Yu., \& Mischuk, N. E. (2017). Diastolic dysfunction of the left ventricle. Medications of Ukraine, 8, 50-56.

[16] Lala, R. I., Lungeanu, D., Darabantiu, D., Pilat, L., \& Puschita, M. (2018). Galectin-3 as a marker for clinical prognosis and cardiac remodeling in acute heart failure. Herz., 43, 146-155. doi: 10.1007/s00059-017-4538-5.

[17] McCullough, P. A., Olobatoke, A., \& Vanhecke, T. E. (2011). Galectin-3: a novel blood test for the evaluation and management of patients with heart failure. Rev. Cardiovasc. Med., 12, 200-210. doi: 10.3909/ricm0624.

[18] Nikonova, E. S., Suslova, T. E, Ryabov, V. V., \& Shurupov, V. S. (2013). Brain natriuretic peptide in patients with chronic heart failure with a reduced and maintained ejection fraction. Clinical laboratory diagnostics, 8, 21-23.

[19] Niu, W., \& Qi, Y. (2010). Association of the angiotensin II type 1 receptor gene $+1166 \mathrm{~A}>\mathrm{C}$ polymorphism with hypertension risk: evidence from a meta-analysis of 16474 subjects. Hypertens Res., 33, 1137-43. doi: 10.1038/hr.2010.156.

[20] Novoyatleva, T., Janssen, W., Wietelmann, A., Schermuly, R. T., \& Engel, F. B. (2013). TWEAK/Fn14 axis is a positive regulator of cardiac hypertrophy. Cytokine, 64, 43-45. doi: 10.1016/j.cyto.2013.05.009.

[21] Pereira, A. R., \& Falcao, L. M. (2015). Galectin-3, a prognostic marker - and a therapeutic target? Revista Portuguesa de Cardiologia, 34, 201-208. doi: 10.1016/j.repc.2014.10.005.

[22] Ponikowski, P., Voors, A. A., Anker, S. D., Bueno, H., Cleland, J. G., Cleland, J. G. F., \& Linde, C. (2016), 2016 ESC guidelines for the diagnosis and treatment of acute and chronic heart failure: the Task Force for the diagnosis and treatment of acute and chronic heart failure of the European Society of Cardiology (ESC) developed with the special contribution of the Heart Failure Association (HFA) of the ESC. Eur. Heart J. 37, 2129-2200. doi:10.1002/ejhf.592.

[23] Poirier, O., Georges, J. L., \& Ricard, S. (1998). New polymorphisms of the angiotensin II type 1 receptor gene and their associations with myocardial infarction and blood pressure: the ECTIM study. Etude Cas-Temoin de l'Infarctus du Myocarde. J. Hypertens., 10, 1443-1447.

[24] Sakovich, O. O., Zhebel, V. M., \& Gumenyuk, A. F. (2011). Inheritance of polymorphic genotypes of the angiotensin II receptor type II type and risk factors for the development of 
hypertonic disease in women living in the Vinnytsia region. Zaporozhye Medical Journal, 4, 44-47.

[25] Starzhinska, O. L., \& Zhebel, V. M. (2005). Features of the course of hypertension in men with different genotypes of the angiotensin II receptor type I. Biomedical and Biosocial Anthropology, 4, 171-177.

[26] Suarez, G., \& Meyerrose, G. (2014). Heart failure and galectin 3. Annals of Translational Medicine, 2, 86-92. doi: 10.3978/ j.issn.2305-5839.2014.09.10.

[27] Tsuleyko, V. J., Matviichuk, N. V., \& Kinoshenko, K. Yu. (2014).
Galectin-3 in patients with chronic heart failure. Ukrainian Cardiology Magazine, 3, 77-81.

[28] Yin Qiu-Sheng, Shi Bing, Dong Lan, \& Bi Lei. (2014). Comparative study of galectin-3 and B-type natriuretic peptide as biomarkers for the diagnosis of heart failure. J. Geriatr. Cardiol., 11, 7982. doi: 10.3969/j.issn.1671-5411.2014.01.014.

[29] Zhang, T., Shao, B., \& Liu, G-A. (2017). Research on clinical value of galectin-3 in evaluating the prognosis of acute heart failure. Europian review for medical and pharmacological sciences, 21, 4406-4410.

\section{ГАЛЕКТИН-3 ЯК МАРКЕР ГІПЕРТРОФІЇ І ДИСФУНКЦІЇ МІОКАРДА У ЧОЛОВІКІВ ХВОРИХ НА ЕСЕНЦІАЛЬНУ ГІПЕРТЕНЗІЮ, НОСІЇВ ПОЛІМОРФНИХ ГЕНІВ РЕЦЕПТОРУ АНГІОТЕНЗИНУ ІІ ТИПУ 1 \\ Ружанска В.О., Сівак В.Г., Сакович О.О., Жебель В.М.}

Однією з основних етіологічних причин виникнення серцевої недостатності є есенціальна гіпертензія. Діагноз серцевої недостатності зазвичай встановлюють на основі аналізу історії хвороби, результатів ехографрічного та біохімічного обстеження хворого. Наявність нормальної фракції викиду не виключає задишку кардіального генезу. Мета - визначити роль галектину-3 як маркера структурно-фрункціональних змін міокарда у чоловіків, хворих на ессенціальну гіпертензію та ХСН носіів поліморфнних генів AT1R, мешканців Подільського регіону України. У зазначеного контингенту обстежених вивчали концентрацію галектину3 та мозкового натрійуретичного пептиду, показники центральної та системної гемодинаміки у носіїв поліморфних варіантів гена рецептору ангіотензину II типу 1 (AT1R) в осіб без серцево-судинної патології $(n=79)$, чоловіків хворих на есенціальну гіпертензію з гіпертрофрією міокарда II-III ступеня ( $n=62)$ та з есенціальнною гіпертензією ( $n=50)$, що ускладнилась хронічною серцевою недостатністю. Генотипування гена AT1R проводили за допомогою полімеразної ланцюгової реакції, рівень галектину3 та мозкового натрійуретичного пептиду - імуноферментним аналізом. Структурно-фуункціональні показники міокарда оцінювали за допомогою ультразвукового дослідження на апараті "PAДМИP ULTIMARA". Отримані дані обробляли математично на персональному комп'ютері з використанням стандартного статистичного пакету Statistica 10,0. Усі дані представлені у вигляді середнього значення (М) та стандартного відхилення $( \pm \sigma)$. Виявлено, що у чоловіків з есенціальною гіпертензією /I стадіі і з есенціальною гіпертензією та хронічною серцевою недостатністю, що виникла на ії тлі, домінують носії алелі $C$ гену рецептору ангіотензину II типу 1. Концентрація галектину-3 та мозкового натрійуретичного пептиду достовірно вища у чоловіків з есенціальною гіпертензією та есенціальною діпертензією і хронічною серцевою недостатністю порівняно з особами без серцево-судинних захворювань, а також у носії алелі С в гені рецептору ангіотензину II типу 1. З'ясовано, що концентрація біомаркерів, що вивчали, була вища в осіб з вираженою та ексцентричною гіпертрофрією лівого шлуночка та при його пониженні фрракції викиду. Дані біомаркери можуть бути використані в комплексній діагностиці гіпертрофрії лівого шлуночка серия при есенціальній гіпертензії та при розвитку у пацієнтів хронічної серцевої недостатності.

Ключові слова: поліморфізм гена рецептору ангіотензину II типу 1 (AT1R), галектин-3, мозковий натрійуретичний пептид, структурно-фуунціональні зміни міокарда, есенціальна гіпертензія, хронічна серцева недостатність.

\section{ГАЛЕКТИН-З КАК МАРКЕР ГИПЕРТРОФИИ И ДИСФУНКЦИИ МИОКАРДА У МУЖЧИН С ЭССЕНЦИАЛЬНОЙ ГИПЕРТЕНЗИЕЙ, НОСИТЕЛЕЙ ПОЛИМОРФНЫХ ГЕНОВ РЕЦЕПТОРА АНГИОТЕНЗИНА ІІ ТИПА 1 \\ Ружанская В.А., Сивак В.Г., Сакович Е.А., Жебель В.Н.}

Одной из основных этиологических причин возникновения сердечной недостаточности является эссенциальная гипертензия. Диагноз сердечной недостаточности обычно устанавливают на основе анализа истории болезни, эхографрического и биохимического обследования больного. Наличие нормальной фрракции выброса не исключает одышку кардиального генеза. Цель - определить роль галектина-3 как маркера структурно-фуннкциональных изменений миокарда у мужчин, больных эссенциальной гипертензией и ХCH носителей полиморфных генов AT1R, жителей Подольского региона Украины. $B$ обозначенном контингенте обследуемых лиц изучали концентрацию галектина-3 и мозгового натрийуретического пептида, показатели центральной и системной гемодинамики у носителей полиморфных вариантов гена рецептора ангиотензина II типа 1 (AT1R) у лиц без сердечно-сосудистой патологии ( $n=79)$, мужчин больных эссенциальной гипертензией с гипертрофрией миокарда II-III степени (n=62) и с эссенциальной гипертензией $(n=50)$, которая усложнилась хронической сердечной недостаточностью. Генотипирование гена AT1R проводили с помощью полимеразной цепной реакции, уровень галектина-3 и мозгового натрийуретического пептида - иммуноферментным анализом. Структурно-фуункциональные показатели миокарда оценивали с помощью ультразвукового исследования на аппарате "РAДMИP ULTIMARA". Полученные данные обрабатывали математически на персональном компьютере с использованием стандартного статистического пакете Statistica 10,0. Bce

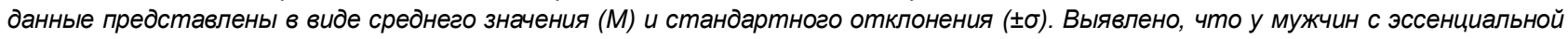
гипертензией II стадии и с эссенциальной гипертензией и хронической сердечной недостаточностью, которая возникла на ее фоне, доминируют носители алели C гена рецептора ангиотензина II типа 1. Концентрация галектина-3 и мозгового натрийуретического пептида достоверно более высокая у мужчин с эссенциальной гипертензией и эссенциальной гипертензией и хронической сердечной недостаточностью по сравнению с лицами без сердечно-сосудистых заболеваний, а также у носителей алели С в гене рецептора ангиотензина II типа 1. Выяснено, что концентрация изучаемых биомаркеров была более высокой у лиц с выраженной и эксцентрической гипертрофией левого желудочка и при его снижении фрракции выброса. Данные биомаркеры могут быть использованы в комплексной диагностике гипертрофии левого желудочка сердца при эссенциальной гипертензии и при развитии у пациентов хронической сердечной недостаточности.

Ключевые слова: полиморфизм гена рецептора ангиотензина II типа 1 (AT1R), галектин-3, мозговой натрийуретический пептид, структурно-фрункциональные изменения миокарда, эссенциальная гипертензия, хроническая сердечная недостаточность. 